\title{
TINJAUAN YURIDIS ADMINISTRASI PUBLIK DAN KEBIJAKAN PUBLIK
}

\author{
Budi Santoso Martono \\ Universitas Islam S yekh-Yusuf, Tangerang \\ bsantosom@unis.ac.id
}

\begin{abstract}
Abstrak
Kata publik sebagai suatu istilah yang berseberangan atau berlawanan dengan konsep - istilah individu atau privat atau perseorangan. Sehingga dari kata publik bisa terkait dengan berbagai konsep kata lain dalam bidang kehidupan sosial, Administrasi Publik mengandung makna bahwa fenomena administrasi yang menjelaskan terhadap kehidupan bersama atau masyarakat, Ketika konsep kebijakan berubah menjadi konsep frasa Kebijakan Publik, maka maknanya adalah Pihak yang berwenang dalam membuat keputusan tersebut adalah “ Penyelenggara Negara “. Dengan demikian kebijakan publik diartikan secara singkat keputusan penyelenggara negara untuk menyelesaikan masalah publik dan merealisir tujuan publik yang yang telah disepakati. Bertolak latar belakang masalah dirumuskan masalah kajian yakni : Faktor- faktor apa yang harus diperhatian Penyelenggara Negara sebagai landasan dalam perumusan, implementasi dan kinerja Kebijakan publik yang dapat dipertanggung jawabkan secara agamis, etis, politis dan yuridis. Sejalan dengan topik tulisan tentang Administrasi Publik dan Kebijakan Publik, maka alasan utama yang melatar belakangi tulisan ini adalah diperolehnya pemahaman yang komprehensif tentang konkritisasi suatu negara, sudah barang tentu dengan fokus negara kita Indonesia, melalui mekanisme kerja dan hasil kerja para Penyelenggara negara dalam memecahkan masalah dan mewujudkan tujuan masyarakatnya melalui pembuatan berbagai kebijakan yang tepat waktu, tepat sasaran dan dapat dipertanggung jawabkan secara agamis, etis, politis dan yuridis. Memperhatikan hal-hal yang telah diuraikan pada bab-bab sebelumnya dapat ditarik kesimpulan sebagai berikut :a. Terdapat 3 (tiga ) faktor- faktor yang harus diperhatian penyelenggara negara sebagai landasan dalam perumusan, implementasi dan kinerja kebijakan publik yakni : Landasan Spiritualis; Landasan Filosofis; Landasan Etis; b. Terdapat 7 (tujuh ) asas penting administrasi publik dalam pengelolaan kebijakan publik yakni : Asas Kepastian Hukum; Asas Tertib Penyelenggaraan Negara; Asas Kepentingan Umum; Asas Keterbukaan; Asas Proporsionalitas; Asas Profesionalitas; Asas Akuntabilitas, yang dipahami dan diimplementasikan secara komprehensif simultan
\end{abstract}

Kata Kunci : Publik, Administrasi Publik, Kebijakan, Landasan Spiritualis,Landasan Filosofis, Landasan Etis.,

\section{A. Pendahuluan}

Konsep publik, dalam bentuk kata tunggal sangat akrab baik dalam wacana lisan maupun tulisan, di manapun, dan di berbagai forum atau media apapun, dalam suatu kehidupan masyarakat atau kehidupan bersama. Dalam makna umum, kata publik sebagai suatu istilah yang berseberangan atau berlawanan dengan konsep - istilah individu atau privat atau perseorangan. Sehingga dari kata publik bisa terkait dengan berbagai konsep kata lain dalam bidang kehidupan sosial, yang muncul dari konsep publik dalam dimensidimensi politik, ekonomi, budaya, pertahanan, keamanan dan lingkungan 
serta lingkup pembidangan lain. dari pihak-pihak tertentu yang mengkaji dan membicarakannya.

Selanjutnya konsep administrasi, oleh masyarakat dimaknai dalam dua aspek, yakni administrasi dalam arti luas dan administrasi dalam arti sempit. Administrasi dalam arti luas menjelaskan suatu fenomena kehidupan beberapa manusia yang saling bekerjasama untuk mencapai tujuan bersama yang telah disepakati. Sedangkan administrasi dalam arti sempit, menjelaskan suatu rangkaian kegatan yang terkait dengan ketatausahaan, yang mencakup pembuatan, pengiriman dan penyimpangan surat dan atau dokumen yang diperlukan oleh kumpulan orang yang bekerja sama tersebut.

Ketika konsep dalam kata tunggal publik dan administras dihubungkan menjadi frasa " Administrasi Publik " mengandung makna bahwa fenomena administrasi yang menjelaskan terhadap kehidupan bersama atau masyarakat. Konsep masyarakat itu sendiri menjelaskan tentang kumpulan orang-orang tertentu yang mempunyai karakteristik atau identitas spesifik yang berbeda dengan dengan kumpulan orang-orang yang mempunyai karakteristik dan identitas spesifik yang lain. Karakteristik dan spesifik suatu masyarakat tersebut mewujud dalam suatu konsep yang disebut budaya. Di mana budaya itu sendiri mempunyai makna yang demikian luas dan beragam, dan untuk memahami konsep budaya tersebut, secara operasional dalam karya tuis ini budaya diartikan sebagai " rangkaian sistem nilai atau sistem gagasan yang abstrak, rasa, karsa dan karya masyarakat. Dengan kata lain antara konsep masyarakat dan budaya demikian eratnya sehimgga dianalogikan sebagai masing-masing sebagai sisi mata uang. Demikian eratnya konsep masyarakat yang menjunjung tinggi budayanya tersebut melahirkan konsep dalam bentuk frasa adalah "sosial budaya ".

Budaya yang ada dalam masyarakat itu sangat beragam, sehingga ketika bicara masyarakat secara empiris, dapat dilihat adanya faktor pembeda tertentu sehingga muncul frasa-frasa masyarakat. Frasa frasa yang lahir dari konsp kata tunggal masyarakat tersebut, berupa konsepkonsep, antara lain : Masyarakat Jawa, Masyarakat Minang, Masyarakat Dayak, Masyarakat Bugis, Masyarakat Sunda, Masyarakat Papua, Masyarakat Bali, Masyarakat Muslim, Masyarakat Kristiani, Masyarakat Budhis, Masyarakat Hiindu, Masyarakat Desa, Masyarakat Kota, Masyarakat Industri, Masyarakat di wilayah tertentu ( Desa, Kelurahan, Kecamatan, Kabupaten, Provinsi dan bahkan negara ), bahkan muncul konsep masyarakat dunnia “ global society “.

Selanjutnya konsep kebijakan itu sendiri, dimaknai sebagai konsep yang dalam bahasa Inggeris disebut “ Policy ", yang secara sederhana diartikan sebagai serangkaian keputusan yang dibuat oleh Pihak yang berwenang untuk menyelesaikan masalah dan/atau untuk mencapai tujuan, sasaran yang ingin diwujudkan. Ketika konsep kebijakan berubah menjadi konsep frasa Kebijakan Publik, maka maknanya adalah Pihak yang berwenang dalam membuat keputusan tersebut adalah “ Penyelenggara Negara “. Dengan demikian kebijakan publik diartikan secara singkat keputusan penyelenggara negara untuk menyelesaikan masalah publik dan merealisir tujuan publik yang yang telah disepakati. Masalah publik dan tujuan publik yang telah disepaktati tadi berupa terwujudnya 
kehidupan yang aman dan sejahtera bagi masyarakat.

Sejalan dengan topik tulisan tentang Administrasi Publik dan Kebijakan Publik, maka alasan utama yang melatar belakangi tulisan ini adalah diperolehnya pemahaman yang komprehensif tentang konkritisasi suatu negara, sudah barang tentu dengan fokus negara kita Indonesia, melalui mekanisme kerja dan hasil kerja para Penyelenggara negara dalam memecahkan masalah dan mewujudkan tujuan masyarakatnya melalui pembuatan berbagai kebijakan yang tepat waktu, tepat sasaran dan dapat dipertanggung jawabkan secara agamis, etis, politis dan yuridis.

Bertitik dari landasan pemikiran bahwa penyelenggara negara dalam menyelenggarakan negara atau mewujudnyatakan kehadiran negara dalam membuat dan merealisir tindakannya yang mampu memecahkan masalah dan menggapai tujuan mayarakat yang dapat dapat dipertanggung jawabkan secara agamis, etis, politis dan yuridis tersebut dapat dirumuskan masalah sebagai berikut :

Faktor- faktor apa yang harus diperhatian Penyelenggara Negara sebagai landasan dalam perumusan, implementasi dan kinerja Administrasi Publik dan Kebijakan Publik yang dapat dipertanggung jawabkan secara agamis, etis, politis dan yuridis.

Dengan menyimak, rumusan masalah pada topik sekaligus judul tulisan ini, dimaksudkan untuk memberikan penjelasan bahwa para Administrator Negara dalam membuat, menimplementasikan dan melakukan evaluasi kinerja kebijakan publik yang diamanatkanya mempunyai implikasi tanggung jawab dunia dan akhirat, Sejalan dengan Maksud Penulisan ini, maka Tujuan Penulisan ini adalah :
Menguraikan dan menjelaskan tentang Faktor- faktor apa yang harus diperhatian Penyelenggara Negara sebagai landasan dalam perumusan, implementasi dan kinerja Kebijakan publik yang dapat dipertanggung jawabkan secara agamis, etis, politis dan yuridis.

Adapun Kegunaan Penulisan ini adalah :1. Bagi penulis bermanfaat untuk memperluas cakrawala berpikir tentang aspek-aspek hubungan antara Administrasi Publik dan Kebijakan Publik; 2. Bagi Universitas Islam Syekh Yusuf Tangerang, sebagai wujud nyata aktivitas dharma penelitian, sebagai pilar kohesif dalam Tri Dharma Perguruan Tinggi; 3. Bagi masyarakat, khususnya para Administrator Negara atau Penyelenggara Negara, hasil kajian ini Regulator, Implementator dan sekaligus sebagai Evaluator Kinerja Kibijakan Publik dapat dipakai sebagai bahan renungan sekaligus intropeksi diri apakah apa yang telah dilakukan sesuai dengan makna, hakikat, landasan dan asas-asas administrasi publik dan kebijakan publik yang baik.

Metode kajian dalam penulisan ini adalah Penilitian Pustaka, yakni mengumpulkan Data Sekunder dengan menggunakan Bahan primer peraturan peruindang-undangan dan Bahan sekunder buku-buku pustaka dan internet, maupun Bahan tersier dari kamus, encyclopedia, dengan pendekatan deskriptif analitis, dan masuk kategori jenis penelitian kualitatif.

\section{Tinjauan Konsepsional}

\section{Konsepsi Administrasi Publik}

Sejalan dengan uraian pada bab Pendahuluan, maka istilah Administrasi Publik menurut Wikipedia, dijelaskan bahwa "Administrasi Publik (Inggris:Public Administration) 
atau Administrasi Negara adalah suatu bahasan ilmu sosial yang mempelajari tiga elemen penting kehidupan bernegara yang meliputi lembaga legislatif, yudikatif, dan eksekutif serta hal- hal yang berkaitan dengan publik yang meliputi kebijakan publik, manajemen publik, administrasi pembangunan, tujuan negara, dan etika yang mengatur penyelenggara negara "(https://id.wikipedia.org/wiki/Administr asi_publik ). Memerhatikan rumusan administrasi publik tersebut dapat diuraikan unsur-unsur dari pengetian administrasi publik adalah : - Ilmu social yang membahas kehidupan bernegara; - Cakupannya adalah lembaga legislatif, yudikatif dan eksekutif;Berkaitan dengan publik yaitu kebijakan publik, manajemen publik, administrasi pembangunan, tujuan Negara dan etika;Mengatur penyelenggaraan Negara,

Berdasar unsur-unsur pengertian administrasi publik, penulis membuat rumusan bahwa administrasi publik adalah ilmu social tentang kehidupan bernegara melalui lembaga-lembaga legislative, yudikatif dan eksekutif dalam menyelenggarakan Negara / publik dalam lingkup kebijakan publik, manajemen publik, administrasi pembangunan, tujuan Negara dan etika.

Selanjutnya untuk memperjelas pemaknaan administrasi publik tersebut berikut diuraikan tentang pengertian publik itu sendiri. Dalam Wikipedia yakni "Publik adalah mengenai orang atau masyarakat, dimiliki masyarakat, serta berhubungan dengan, atau memengaruhi suatu bangsa, negara, atau komunitas. Publik biasanya dilawankan dengan swasta atau pribadi, seperti pada perusahaan publik, atau suatu jalan. Publik juga kadang didefinisikan sebagai masyarakat suatu bangsa yang tidak berafiliasi dengan pemerintahan bangsa tersebut." Jadi publik mencakup pengertian, orang, masyarakat, komunitas, bangsa yang tidak berafilisasi dengan pemerintah sebagai lawan dari swasta atau pribadi.

Pengertian administrasi publik di atas dengan rangkaian kata dalam bentuk pernyataan definisi dinyakakan oleh para ahli sebagai berikut :

John M. Pfiffner : Administrasi publik meliputi pelaksanaan kebijakan negara yang telah ditetapkan oleh badan perwakilan politik

Leonard D. White: Administrasi Publik adalah semua kegiatan atau usaha untuk mencapai tujuan dengan mendasarkan kepada kebijakan Negara.

E.H. Litcfiled : Administrasi Negara adalah suatu studi mengenai bagaimana bermacam-macam badan pemerintah diorganisir, dilengkapi tenaga, tenaganya dibiayai, digerakkan dan dipimpin

Felix A. Nigro: Public Administration : a. Usaha kelompok yang bersifat cooperative di lingkungan pemerintah b. Meliputi seluruh ketiga cabang pemerintah, eksekutif, yudikatif, dan legislatif serta pertalian diantara ketiganya c. Mempunyai peranan penting dalam formulasi kebijaksanaan publik dan merupakan bagian proses politikd. Amat berbeda dengan administrati privat e. Berhubungan erat dengan berbagai macam kelompok. Kelompok privat dan individual dalam memberikan pelayanan publik.

Mc Curdy ( 1986 ): administrasi publik yaitu sebagai salah satu metode pemerintah suatu negara dan dapat dilihat sebagai suatu proses politik serta dapat juga dianggap sebagai cara prinsipil untuk melaksanakan berbagai fungsi negara. Berarti administrasi negara tidak hanya mengurusi soal administrative negara melainkan juga persoalan politik. Orang biasa menyebutnya dengan " Birokrasi ". 
(http://admneg08029.blogspot.com/2010 )

\section{Konsepsi Kebijakan Publik}

Kebijakan publik adalah kebijakankebijakan yang dibuat oleh pemerintah sebagai pembuat kebijakan untuk mencapai tujuan-tujuan tertentu di masyarakat di mana dalam penyusunannya melalui berbagai tahapan, yakni: 1. Penyusunan agenda, adalah sebuah fase dan proses yang sangat strategis dalam realitas kebijakan publik, yakni proses untuk memaknai apa yang disebut sebagai masalah publik dan agenda publik yang perlu diperhitungkan. 2. Formulasi kebijakan. Masalah yang sudah masuk dalam agenda kebijakan kemudian dibahas oleh para pembuat kebijakan. Masalahmasalah tadi didefinisikan untuk kemudian dicari pemecahan masalah yang terbaik. Pemecahan masalah tersebut berasal dari berbagai alternatif atau pilihan kebijakan yang ada. Sama halnya dengan perjuangan suatu masalah untuk masuk dalam agenda kebijakan, dalam tahap perumusan kebijakan masing-masing slternatif bersaing untuk dapat dipilih sebagai kebijakan yang diambil untuk memecahkan masalah. 3. Adopsi/ Legitimasi Kebijakan Tujuan legitimasi adalah untuk memberikan otorisasi pada proses dasar pemerintahan. Jika tindakan legitimasi dalam suatu masyarakat diatur oleh kedaulatan rakyat, warga negara akan mengikuti arahan pemerintah. Namun warga negara harus percaya bahwa tindakan pemerintah yang sah.1. Penilaian/ Evaluasi Kebijakan Secara umum evaluasi kebijakan dapat dikatakan sebagai kegiatan yang menyangkut estimasi atau penilaian kebijakan yang mencakup substansi, implementasi dan dampak. (https://id.wikipedia.org/wiki/Kebijakan _publik)
Pengertian kebijakan publik secara umum tersebut apabila dikemukakan paka sebagai berikut :

Easton (1969)

Pengertian kebijakan publik menurut Easton adalah pengalokasian nilai-nilai kekuasaan untuk seluruh masyarakat yang keberadaannya mengikat

Thomas R. Dye (1981 “... kebijakan publik menurut Thomas R. Dye adalah adalah sebagai apa yang tidak dilakukan maupun apa yang dilakukan oleh pemerintah".

Chandler dan Plano (1988)

Pengertian kebijakan publik menurut Chandler dan Plano adalah pemanfaatan yang strategis terhadap sumber daya sumber daya yang ada untuk memecahkan masalah-masalah publik atau pemerintah.

Jonnes (1977)

Pengertian kebijakan publik menurut Jonnes adalah suatu kelanjutan kegiatan pemerintah di masa lalu dengan hanya mengubahnya sedikit demi sedikit.

Anderson (1975)

Pengertian kebijakan publik menurut Anderson adalah kebijakan-kebijakan yang dibangun oleh badan-badan dan pejabat-pejabat pemerintah.

Chief J. O. Udoji (1981)

Pengertian kebijakan publik menurut Chief J.O Udoji adalah An sanctioned of action addressed to a particular problem or group of related problems that affect society at large. Artinya adalah suatu tindakana bersanksi yang mengarah pada suatu tujuan tertentu yang diarahkan pada suatu masalah atau sekelompok masalah tertentu yang saling berkaitan yang mempengaruhi sebagaian besar warga masyarakat. 


\section{Erward}

Pengertian kebijakan publik menurut Edward adalah What governmernt say and do, or do not do. It is the goals or purposes of governments programs. Artinya apa yang dinyatakan dan dilakukan atau tidak dilakukan oleh pemerintah termasuk kebijakan publik. Woll (1966) Pengertian kebijakan publik menurut Woll adalah sejumlah aktivitas pemerintah untuk memecahkan masalah di masyarakat, baik secara langsung maupun melalui berbagai lembaga yang mempengaruhi kehidupan masyarakat. W.N. Dunn

Pengertian kebijakan publik menurut W.N. Dunn adalah suatu daftar tidakan yang saling berhubungan yang disusun oleh instansi atau pejabat pemerintah antara lain dalam bidang pertahanan, kesehatan, pendidikan, kesejahteraan, pengendalian kriminalitas, dan pembangunan perkotaan. Irfan Islami Pengertian kebijakan publik menurut Irfan Islami adalah serangkaian tindakan yang ditetapkan dan dilaksanakan atau tidak dilaksanakan oleh pemerintah yang mempunyai tujuan atau berorientasi pada tujuan tertentu, demi kepentingan selurh masyarakat. Thomas Dye, Pengertian kebijakan publik menurut Thomas Dye adalah segala sesuatu yang dikerjakan atau tidak dikerjakan oleh pemerintah, mengapa suatu kebijakan harus dilakukan dan apakah manfaat bagi kehidupan bersama harus menjadi pertimbangan yang holistik agar kebijakan tersebut mengandung manfaat yang besar bagi warganya dan berdampak kecil dan sebaliknya tidak menimbulkan persoalan yang merugin, walaupun demikian pasti ada yang diuntungkan dan ada yang dirugikan, disinilah letakanya pemerintah harus bijaksana dalam menetapkan suatu kebijakan.

\section{B. Pembahasan}

Faktor- Faktor Yang Harus Diperhatian Penyelenggara Negara Sebagai Landasan Dalam Perumusan, Implementasi Dan Kinerja Administrasi Publik Dan Kebijakan Publik Yang Dapat Dipertanggung Jawabkan Secara Agamis, Etis, Politis Dan Yuridis Sebagai penyelenggara Negara / Pelaku Administrasi Publik yang merumuskan, mengimplementasikan dan melakukan evaluasi kinerja Kebijakan publik dalam rangka pelayanan publik seharusnya memperhatikan landasan-landasan : spiritualis; filosofis; etis. . Uraian dari masing-masing landasan diuraikan berikut ini.

\section{Landasan Spiritualis;}

Landasan spiritualis dimaknakan sebagai kecerdasan spiritual yang dijelaskan dalam wikipedia bahwa Kecerdasan spiritual (bahasa Inggris: spiritual quotient, disingkat $S Q$ ) adalah kecerdasan jiwa yang membantu seseorang untuk mengembangkan dirinya secara utuh melalui penciptaan kemungkinan untuk menerapkan nilainilai positif.

SQ merupakan fasilitas yang membantu seseorang untuk mengatasi persoalan dan berdamai dengan persoalannya itu. Ciri utama dari SQ ini ditunjukkan dengan kesadaran seseorang untuk menggunakan pengalamannya sebagai bentuk penerapan nilai dan makna. Kecerdasan spiritual yang berkembang dengan baik akan ditandai dengan kemampuan seseorang untuk bersikap fleksibel dan mudah menyesuaikan diri dengan lingkungan, memiliki tingkat kesadaran yang tinggi, mampu menghadapi penderitaan dan rasa sakit, mampu mengambil pelajaran yang berharga dari suatu kegagalan, mampu mewujudkan hidup sesuai dengan visi dan misi, mampu melihat 
keterkaitan antara berbagai hal, mandiri, serta pada akhirnya membuat seseorang mengerti akan makna hidupnya.

\section{Landasan Filosofis;}

Pertimbangan atau alasan yang menggambarkan bahwa peraturan yang dibentuk mempertimbangkan pandangan hidup, kesadaran, dan cita hukum yang meliputi suasana kebatinan serta falsafah bangsa Indonesia yang bersumber dari Pancasila dan Pembukaan UndangUndang Dasar Negara Republik Indonesia Tahun 1945. Berikut diuraikan Landasan Filosofis Pancaila sebagai berikut. Pancasila adalah ideologi dasar dalam kehidupan bagi negara Indonesia. Nama ini terdiri dari dua kata dari Sanskerta: pañca berarti lima dan ślla berarti prinsip atau asas. Pancasila merupakan rumusan dan pedoman kehidupan berbangsa dan bernegara bagi seluruh rakyat Indonesia. Lima sendi utama penyusun Pancasila adalah Ketuhanan Yang Maha Esa, kemanusiaan yang adil dan beradab, persatuan Indonesia, kerakyatan yang dipimpin oleh hikmat kebijaksanaan dalam permusyawaratan/perwakilan, dan keadilan sosial bagi seluruh rakyat Indonesia, dan tercantum pada alinea ke4 Preambule (Pembukaan) UndangUndang Dasar 1945. Majelis Permusyawaratan Rakyat telah membuat keputusan politik membuat jabaran silasila Pancasila dalam Ketetapan MPR No.II/MPR/1978 yang dikenal sebagai butir-butir pengamalan Pancasila, yaitu :1. Ketuhanan Yang Maha Esa, a. Percaya dan takwa kepada Tuhan Yang Maha Esa sesuai dengan agama dan kepercayaan masing-masing menurut dasar kemanusiaan yang adil dan beradab.b. Hormat menghormati dan bekerja sama antar pemeluk agama dan penganut-penganut kepercayaan yang berbeda-beda sehingga terbina kerukunan hidup.c. Saling menghormati kebebasan menjalankan ibadah sesuai dengan agama dan kepercayaannya. D. Tidak memaksakan suatu agama dan kepercayaan kepada orang lain.2. Kemanusiaan yang adil dan beradab, a.Mengakui persamaan derajat persamaan hak dan persamaan kewajiban antara sesama manusia.b. Saling mencintai sesama manusia.c. Mengembangkan sikap tenggang rasa.d. Tidak semena-mena terhadap orang lain.e. Menjunjung tinggi nilai kemanusiaan.

f. Gemar melakukan kegiatan kemanusiaan.g.Berani membela kebenaran dan keadilan.h.Bangsa Indonesia merasa dirinya sebagai bagian dari seluruh umat manusia, karena itu dikembangkan sikap hormatmenghormati dan bekerja sama dengan bangsa lain.3.Persatuan Indonesia a.Menempatkan kesatuan, persatuan, kepentingan, dan keselamatan bangsa dan negara di atas kepentingan pribadi atau golongan.b.Rela berkorban untuk kepentingan bangsa dan negara.c.Cinta tanah air dan bangsa.d.Bangga sebagai bangsa Indonesia dan bertanah air Indonesia..d. Memajukan pergaulan demi persatuan dan kesatuan bangsa yang berBhinneka Tunggal Ika.4. Kerakyatan yang dipimpin oleh hikmat kebijaksanaan dalam permusyawaratan dan perwakilan, a. Mengutamakan kepentingan negara dan masyarakat.b. Tidak memaksakan kehendak kepada orang lain.c. Mengutamakan musyawarah dalam mengambil keputusan untuk kepentingan bersama.d. Musyawarah untuk mencapai mufakat diliputi semangat kekeluargaan. e. Dengan iktikad baik dan rasa tanggung jawab menerima dmelaksanakan hasil musyawarah. f. Musyawarah dilakukan dengan akal sehat dan sesuai dengan hati nurani yang luhur.g.Keputusan yang diambil harus dapat dipertanggung 
jawabkan secara moral kepada Tuhan Yang Maha Esa, menjunjung tinggi harkat dan martabat manusia serta nilainilai kebenaran dan keadilan. 5. Keadilan sosial bagi seluruh rakyat Indonesia. a. Mengembangkan perbuatan-perbuatan yang luhur yang mencerminkan sikap dan suasana kekeluargaan dan gotong-royong..b. Bersikap adil. c.Menjaga keseimbangan antara hak dan kewajiban.d.Menghormati hak-hak orang lain. e.Suka memberi pertolongan kepada orang lain.f.Menjauhi sikap pemerasan terhadap orang lain.g.Tidak bersifat boros.h.Tidak bergaya hidup mewah.i.Tidak melakukan perbuatan yang merugikan kepentingan umum.j.Suka bekerja keras.k.Menghargai hasil karya orang lain.l.Bersama-sama berusaha mewujudkan kemajuan yang merata dan berkeadilan, Selanjutnya berdasarkan K etetapan MPR no. I/MPR/2003 diuraikan sebagai berikut : Sila pertama Bintang.1.Bangsa Indonesia menyatakan kepercayaannya dan ketakwaannya terhadap Tuhan Yang Maha Esa.2.Manusia Indonesia percaya dan takwa terhadap Tuhan Yang Maha Esa, sesuai dengan agama dan kepercayaannya masing-masing menurut dasar kemanusiaan yang adil dan beradab.3.Mengembangkan sikap hormat menghormati dan bekerja sama antara pemeluk agama dengan penganut kepercayaan yang berbeda-beda terhadap Tuhan Yang Maha Esa.4.Membina kerukunan hidup di antara sesama umat beragama dan kepercayaan terhadap Tuhan Yang Maha Esa.5.Agama dan kepercayaan terhadap Tuhan Yang Maha Esa adalah masalah yang menyangkut hubungan pribadi manusia dengan Tuhan Yang Maha Esa.6.Mengembangkan sikap saling menghormati kebebasan menjalankan ibadah sesuai dengan agama dan kepercayaannya masingmasing.7.Tidak memaksakan suatu agama dan kepercayaan terhadap Tuhan Yang Maha Esa kepada orang lain..Sila kedua. Rantai.1.Mengakui dan memperlakukan manusia sesuai dengan harkat dan martabatnya sebagai makhluk Tuhan Yang Maha Esa.2. Mengakui persamaan derajat, persamaan hak, dan kewajiban asasi setiap manusia, tanpa membeda-bedakan suku, keturunan, agama, kepercayaan, jenis kelamin, kedudukan sosial, warna kulit dan sebagainya.1.Mengembangkan sikap saling mencintai sesama manusia.2.Mengembangkan sikap saling tenggang rasa dan tepa selira.3.Mengembangkan sikap tidak semena-mena terhadap orang lain.4.Menjunjung tinggi nilai-nilai kemanusiaan.5.Gemar melakukan kegiatan kemanusiaan. 6. Berani membela kebenaran dan keadilan.7.Bangsa Indonesia merasa dirinya sebagai bagian dari seluruh umat manusia.8.Mengembangkan sikap hormat menghormati dan bekerja sama dengan bangsa lain. Sila ketiga. Pohon Beringin 1. Mampu menempatkan persatuan, kesatuan, serta kepentingan dan keselamatan bangsa dan negara sebagai kepentingan bersama di atas kepentingan pribadi dan golongan.2.Sanggup dan rela berkorban untuk kepentingan negara dan bangsa apabila diperlukan. 3.Mengembangkan rasa cinta kepada tanah air dan bangsa. 4.Mengembangkan rasa kebanggaan berkebangsaan dan bertanah air Indonesia.5,Memelihara ketertiban dunia yang berdasarkan kemerdekaan, perdamaian abadi, dan keadilan sosial.6.Mengembangkan persatuan Indonesia atas dasar Bhinneka Tunggal Ika.7.Memajukan pergaulan demi persatuan dan kesatuan bangsa..Sila keempat.Kepala Banteng.1.Sebagai warga negara dan warga masyarakat, setiap manusia Indonesia mempunyai kedudukan, hak, dan kewajiban yang sama. 2.Tidak boleh memaksakan 
kehendak kepada orang lain.3.Mengutamakan musyawarah dalam mengambil keputusan untuk kepentingan bersama.4.Musyawarah untuk mencapai mufakat diliputi oleh semangat kekeluargaan.5.Menghormati dan menjunjung tinggi setiap keputusan yang dicapai sebagai hasil musyawarah.6.Dengan iktikad baik dan rasa tanggung jawab menerima dan melaksanakan hasil keputusan musyawarah.7. Di dalam musyawarah diutamakan kepentingan bersama di atas kepentingan pribadi dan golongan.8. Musyawarah dilakukan dengan akal sehat dan sesuai dengan hati nurani yang luhur.9. Keputusan yang diambil harus dapat dipertanggungjawabkan secara moral kepada Tuhan Yang Maha Esa, menjunjung tinggi harkat dan martabat manusia, nilai-nilai kebenaran dan keadilan mengutamakan persatuan dan kesatuan demi kepentingan bersama.10. Memberikan kepercayaan kepada wakilwakil yang dipercayai untuk melaksanakan pemusyawaratan. Sila kelima. Padi dan Kapas. 1. Mengembangkan perbuatan yang luhur, yang mencerminkan sikap dan suasana kekeluargaan dan kegotongroyongan.2.Mengembangkan sikap adil terhadap sesama.3. Menjaga keseimbangan antara hak dan kewajiban.4.Menghormati hak orang lain.5.Suka memberi pertolongan kepada orang lain agar dapat berdiri sendiri.6.Tidak menggunakan hak milik untuk usaha-usaha yang bersifat pemerasan terhadap orang lain.7.Tidak menggunakan hak milik untuk hal-hal yang bersifat pemborosan dan gaya hidup mewah.8.Tidak menggunakan hak milik untuk bertentangan dengan atau merugikan kepentingan umum.9. Suka bekerja keras.10. Suka menghargai hasil karya orang lain yang bermanfaat bagi kemajuan dan kesejahteraan bersama.11. Suka melakukan kegiatan dalam rangka mewujudkan kemajuan yang merata dan berkeadilan sosial.. Selanjutnya uraian tentang landasan filosofis UUD 1945 sebagai berikut : Undang-Undang Dasar Negara Republik Indonesia Tahun 1945, atau disingkat UUD 1945 atau UUD '45, adalah hukum dasar tertulis (basic law), konstitusi pemerintahan

negara Republik Indonesia saat ini. UUD 1945 disahkan sebagai undangundang dasar negara oleh PPKI pada tanggal 18 Agustus 1945. Sejak tanggal 27 Desember 1949, di Indonesia berlaku Konstitusi RIS, dan sejak tanggal 17 Agustus 1950 di Indonesia berlaku UUDS 1950. Dekret Presiden 5 Juli 1959 kembali memberlakukan UUD 1945, dengan dikukuhkan secara aklamasi oleh DPR pada tanggal 22 Juli 1959.

Pada kurun waktu tahun 19992002, UUD 1945 mengalami 4 kali perubahan (amendemen), yang mengubah susunan lembaga-lembaga dalam sistem ketatanegaraan Republik Indonesia. Salah satu tuntutan Reformasi 1998 adalah dilakukannya perubahan (amendemen) terhadap UUD 1945. Latar belakang tuntutan perubahan UUD 1945 antara lain karena pada masa Orde Baru, kekuasaan tertinggi di tangan MPR (dan pada kenyataannya bukan di tangan rakyat), kekuasaan yang sangat besar pada Presiden, adanya pasal-pasal yang terlalu "luwes" (sehingga dapat menimbulkan multitafsir), serta kenyataan rumusan UUD 1945 tentang semangat penyelenggara negara yang belum cukup didukung ketentuan konstitusi. Tujuan perubahan UUD 1945 waktu itu adalah menyempurnakan aturan dasar seperti tatanan negara, kedaulatan rakyat, HAM, pembagian kekuasaan, eksistensi negara demokrasi dan negara hukum, serta hal-hal lain yang sesuai dengan perkembangan aspirasi dan kebutuhan bangsa. Perubahan UUD 1945 dengan kesepakatan di antaranya tidak 
mengubah Pembukaan UUD 1945, tetap mempertahankan susunan kenegaraan (staat structuur) kesatuan atau selanjutnya lebih dikenal sebagai Negara Kesatuan Republik Indonesia (NKRI), serta mempertegas sistem pemerintahan presidensial.

Dalam kurun waktu 1999-2002, UUD 1945 mengalami 4 kali perubahan (amendemen) yang ditetapkan dalam Sidang Umum dan Sidang Tahunan MPR:-Sidang Umum MPR 1999, tanggal 14-21

Oktober $1999 \rightarrow$ Perubahan $\quad$ Pertama UUD 1945- Sidang Tahunan MPR 2000, tanggal 7-18 Agustus $2000 \rightarrow$ Perubahan Kedua UUD 1945- Sidang Tahunan MPR 2001, tanggal 1-9 November $2001 \rightarrow$ Perubahan Ketiga UUD 1945- Sidang Tahunan MPR 2002, tanggal 1-11 Agustus $2002 \rightarrow$ Perubahan Keempat UUD 1945. 3.

\section{Landasan Etis;}

Kata etis sama maknanya dengan etika yang dalam buku "Nilai Norma - Paradigma Etika Administrasi “ yang menguraikan tentang etika sebagai berikut. "Dalam bahasa Indonesia, kata etika diartikan sebagai ilmu tentang apa yang baik dan apa buruk dan tentang hak dan kewajiban moral (akhlak). Adapun kata moral itu sendiri diartikan sebagai :1).Ajaran tentang baik dan buruk yang diterima umum mengenai perbuatan, sikap, kewajiban dan sebagainya; akhlak, budi pekerti, susila; 2).Kondisi mental yang membuat orang tetap berani, bersemangat, bergairah, berdisiplin dan sebagainya. Berdasarkan uraian di atas, maka landasan etis atau etika atau moral atau akhlak atau budi pekerti atau susila Pejabat Penyelenggara Negara sebagai elit politik, antara lain :-Integritas adalah nilai - nilai yang kita percayai, kita perjuangkan, kita pegang yakni kejujuran dan kesetiaan,-Akuntabilitas , merupakan sebuah konsep etika yang dekat dengan administrasi publik pemerintahan ( lembaga eksekutif pemerintah, lembaga. Menurut Brruce Stone, O.P,Dwivedi and Joseph G,Jabora, yang dikutip oleh Budi SM. , menyebutkan jenis-jenis akuntabilitas, yakni :1).Akuntabilitas moral.2)Akuntabilitas administratif.3) Akuntabilitas politik;2).Akuntabilitas manajerial; 3 3).Akuntabilitas pasar:4).Akuntabilitas hukum ;5) Akuntabilitasperadilan;6).Akuntabilitas hubungan dengan konstituen; 7)Akuntabilitas peofesional.- Loyalitas , secara etimologi Bahasa Latin legalis, diartikan hukum atau prinsip. Loyalitas berpijak di atas prinsip-prinsip yang kita miliki dan pegang. Kita tidak mungkin loyal kepada negara kita, jika dalam diri kita tidak tertanam prinsip patriotisme. Kamus Okford Thesaurus mendaftar beberapa kata pendukung arti loyalitas yang terangkum dalam 6 ( enam ) hal yaitu :1).Percaya dan dapat dipercaya. 2)Tidak pura-pura;3).Konsisten dan stabil4).Mengasihi.5).Dedikasi.6).Patriot ik. - Ethos Kerja sebenarnya adalah istilah populer untuk selera bekerja. ... Orang dan organisasi yang punya ethos kerja tentunya menunjukkan semangat untuk berkolaborasi, berdebat, berkomunikasi, berprestasi yang tidak ada matinya, sehingga secara nyata dapat memetik hasil yang riil dan memberi kontribusi bagi kemajuan organisasinya, juga bangsanya. - Kebenaran adalah persesuaian antara pengetahuan dan obyek, bisa juga diartikan sebagai suatu pendapat atau perbuatan seseorang yang sesuai dengan ( atau tidak ditolak oleh ) orang lain dan tidak merugikan diri sendiri.- Keindahan atau keelokan merupakn sifat dan ciri dari orang, hewan, tempat, obyek, atau gagasan yang memberikan pengalaman persepsi kesenangan, bermakna atau kepuasan,Profesionalitas adalah orang yang menyandang suatu jabatan atau 
pekerjaan yang dilakukan dan Penyelenggara Negara.- Keadilan keterampilan yang tinggi. adalah kondisi kebenaran ideal secara Profesionalisme merupakan komitmen moral mengenai sesuatu hal, baik para anggota suatu profesi untuk menyangkut benda atau orang. Keadilan meningkatkan kemampuannya secara adalah meletakkan segala sesuatunya terus menerus. Profesionalisme adalah pada tempatnya. proses atau perjalanan waktu yang membuat seseorang atau kelompok orang menjadi profesional. Profesionalisme merupakan sikap para anggota profesi benar-benar menguasai sungguhsungguh kepada profesinya. - Kepastian Hukum secara normatif adalah ketika suatu peraturan dibuat dan diundangkan secara pasti karena mengatur secara jelas dan logis. Jelas, dalam arti tidak menimbulkan keragu-raguan ( multi tafsir ) dan logis, dalam arti ia menjadi suatu sistem norma dengan norma lain sehingga tidak berbenturan atau menimbulkan konflik norma. Adapun asas kepastian hukum ${ }^{25}$ adalah asas dalam negara hukum yang mengutamakan landasan peraturan perundang-undangan, kepatutan, dan keadilan dalam setiap kebijakan

\section{Kesimpulan}

Memperhatikan hal-hal yang telah diuraikan pada bab-bab sebelumnya dapat ditarik kesimpulan sebagai berikut :a. Administrasi publik adalah ilmu social tentang kehidupan bernegara melalui lembaga-lembaga legislative, yudikatif dan eksekutif dalam menyelenggarakan Negara / publik dalam lingkup kebijakan publik, manajemen publik, administrasi pembangunan, tujuan Negara dan etika

$$
\text { b.Penyelenggara Negara / }
$$

Pelaku Administrasi Publik yang merumuskan, mengimplementasikan dan melakukan evaluasi kinerja Kebijakan publik dalam rangka pelayanan publik seharusnya memperhatikan landasanlandasan : spiritualis; filosofis; dan etis .

\section{Referensi}

Undang-Undang RI Nomor 30 Tahun 2014 TENTANG ADMINISTRASI PEMERINTAHAN - LN RI Tahun 2014 Nomor 292 TLN RI Nomor 5601. Pasal 1, Butir 1 -

Undang - Undang RI Nomor 44 Tahun 2006 TENTANG PORNOGRAFI, LN RI Tahun 2008 Nomor 181 TLN RI Nomor 4928 .Pasal 1, Butir 5. Undang-Undang Republik Indonesia Nomor 28 Tahun 1999 Tentang Penyelenggaraan Negara Yang Bersih Dan Bebas Dari Korupsi, Kolusi, Dan Nepotisme Tambahan Lembaran Negara Republik Indonesia Nomor 3851,

Undang - Undang RI Nomor 25 Tahun 2009 TENTANG PELAYANAN PUBLIK, LN RI Tahun 2009 Nomor 112 TLN RI Nomor 5038

Martono, Budi Santoso, Pilar - Pilar Kebangsaan Pancasila - UUD 1945 - NKRI Bhinneka Tunggal Ika, Tangerang : CV. Labagus, 2016, hal. 110 -111, Pendidikan Kewarganegaraan - Modul Mahasiswa Perguruan Tinggi,

Tangerang : CV. Labagus, 2016, Nilai - Norma - Paradigma Etika Administrasi, Tangerang : CV. Labagus, 2015-

Varma., S.P, Teori Politik Modern., Jakarta : Rajawali Pers, Mei 1987, hal.202. 